Kıratl1, E., Ersöz, G., Koçak, E. / Journal of Yasar University, 2021, 16/63, 1207-1217

\title{
Sosyal Görünüş Kaygısının İşyeri Yalnızlığına Etkisi: Konya Gençlik ve Spor İl Müdürlüğü Örneği
}

\section{The Effects of Social Apperance Anxiety on Workplace Loneliness: A Review on Sport Organization}

\author{
Esin KIRATLI, Gençlik ve Spor Bakanlığı, Türkiye, esinkr@hotmail.com, \\ Orcid No: 0000-0002-5182-7660 \\ Gözde ERSÖZ, Fenerbahçe Üniversitesi, Türkiye,gözde. ersoz@fbu.edu.tr \\ Orcid No: 0000-0002-4848-1929 \\ Emine KOÇAK, Gençlik ve Spor Bakanlığı, Türkiye, emnkocak@ hotmail.com \\ Orcid No: 0000-0003-3384-3058
}

\begin{abstract}
Öz: İsyeri sağllğ̆ psikolojisi son zamanlarda psikologlar, yönetim bilimcileri ve sosyologlar tarafindan sikllkla araştırlan konulardan biri haline gelmiştir. İsyerinde bireyin sosyal çevreden kaynaklanan yalnız kalma hali ve sosyal etkileşimin kaçınılmaz bir bileşeni olan sosyal görünüs kaygısı işyerindeki psikolojik sağlığı etkileyen faktörlerden bazılarıdır. Bu çalı̧̧manın amacl, spor teşkilatında çalışan personelin sosyal görünüş kaygılarının iş yeri yalnızlı̆̆na etkisini belirlemek ve bazı demografik özelliklerin (yaş ve çallşma süresi) söz konusu psikolojik faktörler ile iliş̧kisini ortaya koymaktır. Bu amaç doğrultusunda araştırmanın örneklemini Konya Gençlik ve Spor Il Müdürlüğü'nde antrenör, memur ve uzman olarak görev yapan toplam 192 çallşan $\left(n_{\text {erkek }}=127 ; X_{\text {yas }}=37.73\right.$ \pm 7.74 ve $\left.n_{\text {kadın }}=65 ; X_{\text {yas }}=36.39 \pm 8.17\right)$ olușturmaktadır. Çalıșmada "İsyerinde Yalnızlı Ölçeği" ve "Sosyal Görünüş Kaygısı Ölçeği" kişisel bilgi formu ile birlikte örneklem grubuna uygulanmuştır. Verilerin analizinde betimsel istatistik yöntemleri, Pearson Momentler Çarpımı Korelasyon Analizi ve Basit Regresyon Analizi kullanılmıştır. Elde edilen bulgulara göre Gençlik ve Spor çalıșanlarının sosyal görünüş kaygısı düzeylerinin İsyerinde Yalnızlık Ölçeğgi' nin duygusal yoksunluk ve sosyal arkadaşlık alt boyutlarını pozitif yönde yordadı̆̆g görülmüştür. Ayrıca sosyal görünü̧s kaygısı ile çalı̧̧ma süresi arasında pozitifiliş̧ki gözlenmişstir. Bu araştırmadan elde edilen veriler ışı̆̆ında, gençlik ve spor çalışanlarında sosyal görünüş̧ kaygısı arttıkça işyerinde yalnızlık durumunu ortaya koyan iş yerindeki bireylerle ilişskilerin niteliğinin ve niceliğinin olumsuz yönde etkilendiği; çalıșma süresi daha fazla olan bireylerin sosyal görünüs algısl yönünde olumsuz duygulara sahip olduğu sonucuna varılmıştır.
\end{abstract}

Anahtar Kelimeler: İ̧̧yeri Yalnızlı̆̆g, Sosyal Görünüş Kayglsl, Gençlik ve Spor

JEL Sinuflandirmasl: D23, J80, L83

Abstract: Workplace health psychology has recently become one of the topics frequently studied by psychologist, management scientists and sociologists. The loneliness of the indvidual due to the social environment in the workplace and social appearance anxiety, which is an inevitable component of social interaction, are some of factors affecting the psychological health in the workplace The aim of this research is to invastigate the affects of employees' social appearance anxiety on workplace lonelines in sports organization and also to examine the relations with employees some demographic status (age and working time). In accordance with this aim, the sample of this study was consisted 192 employees (trainer, expert, civil servant) at Konya Youth and Sport Directory. Social Appearance Anxiety Scale, Workplace Loneliness Scale and personal information form were applied to participants.Descriptive statistics, correlation and regression analysis were used to analyze the data. There were positive correlation between the level of social appearance anxiety and sub-dimensions of workplace loneliness which are emotional deprivation and social friendship. There was also a positive correlation between social appearance anxiety and employees' working time. As a result of this study, it was found that as the social appearance anxiety of youth and sports employees increased, the quality and quantity of relationships with individuals at the workplace, which revealed the loneliness in the workplace, were negatively affected; It was concluded that individuals with longer working hours have negative feelings in terms of social appearance perception.

Keywords: Workplace Loneliness, Social Appearance Anxiety, Youth and Sport

JEL Classification: D23, J80, L83

Makale Gecmiși / Article History

Başvuru Tarihi / Date of Application

Kabul Tarihi / Acceptance Date
: 5 Mayıs / May 2021

: 30 Mayıs / May 2021 


\section{Giriş}

İnsan, sosyal bir varlık olarak çevresindeki diğer insanlarla etkileşim içerisinde olma ve sağlıklı ilişkiler kurma gereksinimindedir. Bu gereksinimin karşılanamadığı durumlarda yalnızlık, ortaya çıkan olumsuzluklardan bir tanesidir. Yalnızlık, bireyin kişilerarası ilişkilerinin sınırlandırması, bu nedenle sosyal etkileşiminin azalması sonucu yaşadığı durum olarak ifade edilir ve bireyin hayatının her alanında görülebileceği gibi, iş hayatında da görülmektedir (Akbaba, 2020; Aykan ve ark., 2019). İş yaşamında yalnızlık, işyerinde diğer çalışanların arasında kişinin kendisini yalnız hissetmesidir (Akbaba, 2020; Doğan ve ark., 2009). Bu yalnızlık, kişinin yaşam ve iş tatminini, ekip çalışmasını olumsuz yönde etkileyebilmektedir (Cindiloğlu Demirer ve ark., 2017; Zhou, 2018). Yalnızlık üzerine yapılan önceki araştırmalar, çoğunlukla kişilik özellikleri gibi kişilik faktörlerine odaklanmış ve özellikle çalışma ortamının etkisi olmak üzere çevresel ve psikolojik faktörler göz ardı edilmiştir. Wright (2005) işyerinde çeşitli karmaşık kişilerarası ilişkilerin olduğunu ve çalışanların bu ilişkileri temel sosyal düzeyde idare edememesi durumunda bir yalnızlık duygusu geliştirmenin kolay olduğunu belirtmiştir. Lam ve Lau (2012) ayrıca, işyerinde, iletişim teknolojisinin popülerliği ve sanal ekiplerin ortaya çıkması nedeniyle, çoğu çalışanın farklı teknolojik iletişim yolları aracılığıyla bilgi ilettiğini, yüz yüze iletişim firsatlarının azaldığını ve işyeri rekabeti, organizasyonun üyeleri arasındaki samimi temasların sürdürülmesini zorlaştırarak işyerinde yalnızlığın arttığını ortaya koymuştur. Psikolojik, sosyolojik ve fiziksel olarak yalnızlık hissine kapılan bir kişiden tutarlı ve olumlu davranış sergilemesi beklenmemektedir (Gafa ve Dikmenli, 2019; Zhou, 2018).

Sosyal yaşamında sağlıklı ve sağlam ilişkileri olan ve yalnızlık hissi yaşamayan bir birey, iş yaşamında sağlıklı ilişkiler kurmakta zorluk çekebilir ve bunun sonucu olarak yalnız kalabilir (Özmen, 2020; Sever ve Paksoy, 2019). Bunun tam tersi olarak, sosyal hayatında yalnız hisseden bir kişi, iş hayatında mutlu hissedebilir ve sağlıklı ilişkiler kurabilir (Parlak ve Koçoğlu Sazkaya, 2018). Wright ve arkadaşları (2006) iş yaşamında yalnızlığın iki alt boyuttan oluştuğunu belirtmektedir. Bunlar "duygusal yoksunluk" ve sosyal arkadaşlık” tır. Duygusal yoksunluk işyerinde ilişkilerin duygusal niteliğini; sosyal arkadaşlık ise niceliğini ifade eder (Doğan ve ark., 2009). Duygusal yoksunluk, çalışanın kendisini işyerindeki sosyal çevrenin bir parçası olarak görememesi ve sosyal çevreye katılmakta zorlanması durumudur (Bilgener ve Çankaya, 2019). Sosyal arkadaşlık boyutundan kaynaklanan yalnızlık ise çalışanın diğer çalışanlarla iletişiminin yetersiz olduğu ve çalışma ortamında kendilerini sosyal arkadaş grubunun bir parçası olarak görememelerinden kaynaklanmaktadır (Çetin ve Alacalar, 2016). Bireylerin çalışma hayatında yalnızlık hisleri, çalıştıkları ortamların dinamikleri ile yakından 
ilişkili olmakla birlikte, kişinin özgüveninin yetersiz olması ve iş arkadaşları ile ilişkilerindeki yetersizlikten kaynaklı ortaya çıkabilmektedir (Koçak ve Tunç, 2020; Koçer ve ark., 2018; Özmen, 2020). İşyerinde yalnızlık hisseden birey, stres ve duygusal problemler yanında fiziksel sorunlar da yaşayabilmektedir (Doğan ve ark., 2009; Cacioppo ve ark., 2010).

Günümüzde insanların çoğu, fiziksel görünüşü düzgün kişilerle daha çok iletişim kurmak istemekte; bu nedenle diğer insanlar üzerinde olumlu bir izlenim bırakmak ve güzel görünmek için çaba göstermektedir (Göksel ve ark., 2018). Bir insanın diğer insanlara olan tutumunu belirleyen ilk bilgi kişilerin dış görünüşüdür ve insanlar iletişim kurmadan önce birbirlerinin dış görünüşünü değerlendirirler (K1lıç, 2015; Korkmaz ve Uslu, 2020). Diş görünüşleri ile etkili ve olumlu bir izlenim bırakamayacaklarını hissettiklerinde ise kaygı yaşarlar (Göksel ve ark., 2018). Sosyal kaygının bir çeşidi olarak karşımıza çıkan sosyal görünüş kaygısı, bireyin fiziksel görünümünün diğer kişiler tarafından değerlendirilirken, bireyin yaşadığı duygusal tepki ve kayg1 olarak ifade edilmektedir (Doğan, 2010; Göksel ve ark., 2018; Hart ve ark. 2008). Bu kaygı insanın sadece bedeni üzerinden duyduğu endişe ile ilişkili bir durum olmayıp, insanın görünümü ile ilişkilendirilebilen bütün değerlendirmelerle ilgili bir durumdur. Yani kişinin fiziksel görünüşü ile ilgili olumsuz beden imajıdır (Doğan, 2010; Koçak ve Şimşek, 2018; Yazıcı ve ark., 2016). Olumsuz beden imajı kişinin bedeni hakkında iyi hissedememesine ve bedenini kabul edememesine neden olmaktadır (Kara, 2016). Ayrıca kişinin sosyal görünüşüne ilişkin olumsuz duyguları, kişinin kendisini değersiz, zayıf ve yalnız hissetmesine, bununla birlikte yakın ilişki kurmaktan kaçınmasına sebep olur (Çakmak ve Sakarya 2020; Eren Gümüş, 2000; Kılıç ve Karakuş, 2016). Yapılan araştırmalarda iyi görünümlü insanların sosyal ve iş hayatlarında ve kişisel ilişkilerinde daha avantajlı oldukları sık sık vurgulanmaktadır (Şimşir ve Dilmaç, 2019). Önceki araştırmalar incelendiğinde iş yeri yalnızlığı ve sosyal görünüş kaygısı konusuna çok çalışma yapıldığını fakat bu iki psikolojik kavramın birbiri ile ilişkisine bakılmadığı görülmüştür. Sosyal görünüşten memnuniyetsiz olmanın kişileri çalıştıkları ortamda yalnızlığa yöneltebileceği düşünülmektedir. Bu bilgiler 1şığında çalışmanın amacı, Konya Gençlik ve Spor İl Müdürlüğü'nde çalışan personelin iş yaşamında yalnızlık durumları ile sosyal görünüş kaygıları arasındaki ilişkiyi incelemektir. Bu amaç doğrultusunda aşağıda belirtilen hipotezler test edilmiştir.

H1: Konya Gençlik ve Spor İl Müdürlüğü çalışanlarının sosyal görünüş kaygısı düzeyleri İşyerinde Yalnızlık Ölçeği’nin duygusal yoksunluk alt boyutunu pozitif yönde yordamaktadır. H2: Konya Gençlik ve Spor İl Müdürlüğü çalışanlarının sosyal görünüş kaygısı düzeyleri İşyerinde Yalnızlık Ölçeği’nin sosyal arkadaşlık alt boyutunu pozitif yönde yordamaktadır. 
H3: Konya Gençlik ve Spor İl Müdürlüğü çalışanlarının sosyal görünüş kaygısı, duygusal yoksunluk, sosyal arkadaşlık ile yaş ve çalışma süresi arasında anlamlı bir ilişki yoktur.

\section{Yöntem}

\subsection{Araştırma Modeli}

Araştırma modeli olarak sosyal görünüş kaygısı ile işyeri yalnızlığı arasındaki ilişkiyi incelemek amacıyla ilişkisel tarama modeli tercih edilmiştir. Araştırmanın, bağımsız değişkeni sosyal görünüş kaygısı; bağımlı değişkeni ise işyeri yalnızlığıdır.

\subsection{Araştırma Grubu}

Araştırmanın örneklemini, Konya Gençlik ve Spor İl Müdürlüğ̈̈'nde antrenör, memur ve uzman olarak görev yapan, yaşları 21-55 arasında değişen toplam 192 çalışan oluşturmaktadır. Kadın çalışanların yaş ortalaması $36.39( \pm 8.17)$, erkek çalışanların yaş ortalamaları ise 37.73 $( \pm 7.74)$ yıldır. Katılımcılara yönelik tanımlayıcı istatistikler Tablo 1' de verilmiştir.

Tablo 1. Kat1lımc1 istatistikleri

\begin{tabular}{|c|c|c|c|c|c|c|}
\hline \multirow[b]{2}{*}{ Yaş grubu } & \multicolumn{2}{|c|}{$\begin{array}{l}\text { Kadın } \\
(n=65)\end{array}$} & \multicolumn{2}{|c|}{$\begin{array}{c}\text { Erkek } \\
(n=127)\end{array}$} & \multicolumn{2}{|c|}{$\begin{array}{l}\text { Toplam } \\
(n=192)\end{array}$} \\
\hline & $f$ & $\%$ & $f$ & $\%$ & $f$ & $\%$ \\
\hline 25 yaş ve aşağ 1 & 5 & 7.69 & 3 & 2.36 & 8 & 4.17 \\
\hline 26-34 yaş & 30 & 46.15 & 47 & 37.01 & 77 & 40.10 \\
\hline 35-44 yaş & 19 & 29.23 & 52 & 40.94 & 71 & 36.98 \\
\hline 45 yaş ve ustu & 11 & 16.92 & 25 & 19.69 & 36 & 18.75 \\
\hline Medeni durum & $f$ & $\%$ & $f$ & $\%$ & $f$ & $\%$ \\
\hline Bekar & 18 & 27.69 & 27 & 21.26 & 45 & 22.97 \\
\hline Evli & 47 & 72.31 & 100 & 78.74 & 147 & 76.56 \\
\hline Ĕgitim & $f$ & $\%$ & $f$ & $\%$ & $f$ & $\%$ \\
\hline Lise & 7 & 10.77 & 15 & 11.81 & 22 & 11.46 \\
\hline Önlisans & 9 & 13.85 & 7 & 5.51 & 16 & 8.33 \\
\hline Lisans & 35 & 53.85 & 79 & 62.20 & 114 & 59.38 \\
\hline Lisansüstü & 14 & 21.54 & 26 & 20.47 & 40 & 20.83 \\
\hline Unvan & $f$ & $\%$ & $f$ & $\%$ & $f$ & $\%$ \\
\hline Antrenör & 19 & 29.23 & 59 & 46.46 & 78 & 40.63 \\
\hline Uzman & 20 & 30.77 & 35 & 27.56 & 55 & 28.65 \\
\hline Memur & 26 & 40.00 & 33 & 25.98 & 59 & 30.73 \\
\hline Çalışma süresi & $f$ & $\%$ & $f$ & $\%$ & $f$ & $\%$ \\
\hline 5 yas ve alt 1 & 14 & 21.54 & 33 & 25.98 & 47 & 24.48 \\
\hline $6-10$ yıl & 22 & 33.85 & 46 & 36.22 & 68 & 35.42 \\
\hline $11-15$ y1l & 14 & 21.54 & 23 & 18.11 & 37 & 19.27 \\
\hline
\end{tabular}




\subsection{Veri Toplama Araçları}

Araştırmamıza katılan çalışanların demografik özelliklerini belirlemek için Kişisel Bilgi Formu, iş yaşamında yalnızlık durumlarını belirlemek için İşyerinde Yalnızlık Ölçeği ve sosyal görünüş kaygılarını belirlemek için ise Sosyal Görünüş Kaygısı Ölçeği kullanılmıştır.

Kişisel Bilgi Formu: Çalışanların cinsiyet, yaş, medeni durum, eğitim durumu, mesleki unvan ve kurumda çalışma süresi gibi özelliklerini belirlemek için araştırmacılar tarafından hazırlanmıştır.

Issyerinde Yalnızlık Ölçeği (IYÖ): İş yaşamında yalnızlık düzeyini belirlemek üzere Wright ve arkadaşları (2006) tarafından geliştirilen 16 ifadeli İşyerinde Yalnızlık Ölçeği (İYÖ) kullanılmıştır. Bu ölçekte sorular "İ̧̧ ortamında baskı altındayken iş arkadaşlarım tarafindan yalnız bırakıldı̆̆ımı hissederim" ve "Işs yerinde istediğimde kişisel düşüncelerimi paylaşabileceğim kimse yoktur” şeklindedir. Ölçek "Sosyal Arkadaşlık” (7 madde) ve "Duygusal Yoksunluk" (9 madde) olarak iki alt boyuttan oluşmaktadır. Ölçek 5'li Likert şeklinde olup, Kesinlikle katılmıyorum (1)'dan Kesinlikle katılıyorum (5)' a kadar değerlendirilmektedir. Ölçeğin Türkçe’ye geçerlemesi Doğan ve arkadaşları (2009) tarafından yapılmıştır ve Cronbach alfa katsayısı .82 olarak tespit edilmiştir. $\mathrm{Bu}$ araştırmada ise ölçeğin Cronbach alfa katsayısı .92 olarak tespit edilmiştir.

Sosyal Görünüş Kayglsı Ölçeği (SGKÖ): Sosyal Görünüş Kaygısı Ölçeği, bireylerin sosyal görünüş kaygılarını ölçmek amacıyla Hart ve ark. (2008) tarafından geliştirilmiştir. Ölçek 16 maddelik, beşli Likert tipinde tek boyutlu, öz bildirim (self-report) tarzı bir ölçektir. SGKÖ, bireylerin görünüş kaygıları ile ilgili bilişsel, duyuşsal ve davranışsal ifadelerden oluşmaktadır. Ölçeğin Türkçe uyarlaması Doğan (2009) tarafından yapılmış ve güvenirlilik katsayısı .88'dir. Yapı geçerliliği yapıldığında ölçeğin tek boyutlu olarak geçerli olduğu belirlenmiştir. Ölçeğin Türkçe formunun madde-toplam korelasyon katsayılarının .32 ile .82 arasında olduğu sonucuna ulaşılmıştır. Bu çalışmada ölçeğin iç tutarlılık katsayısı .91 olarak yüksek derecede güvenilir bulunmuştur.

\subsection{Verilerin Analizi}

Verilerin analizinde araştırma grubunun özelliklerinin tanımlanması için betimsel istatistik analizi (ortalama ve standart sapma) yapılmıştır. Araştırmada elde edilen verilerin analizine ve bulguların yorumlanmasına geçilmeden önce normallik, doğrusallık, çoklu ve varyanskovaryans matrislerinin homojenlik varsayımların karşılanıp karşılanmadı̆̆ incelenmiştir (Tabachnick ve Fidell, 2001). Bağımlı değişkenler arasında ilişkilerin doğrusal olup olmadığı 
saçılım grafikleri aracılığı ile incelenmiş ve her bağımlı değişken arasında doğrusallık varsayımının karşılandığı görülmüştür. Araştırmada ele alınan sosyal görünüş kaygısı, İşyeri Yalnızlığı Ölçeği’ nin duygusal yoksunluk ve sosyal arkadaşlık alt boyutları ile katılımcıların yaşları ve çalışma süreleri arasındaki ilişkiyi analiz etmek için pearson momentler çarpımı korelasyon analizi kullanılmıştır. Araştırmada yer alan bireylerin sosyal görünüş kaygılarını İşyeri Yalnızlığı Ölçeği’ nin duygusal yoksunluk ve sosyal arkadaşlık alt boyutlarını yordayıp yordamadı̆̆ basit regresyon analizi ile sınanmıştır.

\section{Bulgular}

Araştırmada yer alan katılımcıların sosyal görünüş kaygıları ve iş yeri yalnızlığının duygusal yoksunluk ve sosyal arkadaşlık alt boyutlarına yönelik betimsel istatistikleri sonuçları Tablo 2 'de yer almaktadir.

Tablo 2. Katılımcıların sosyal görünüş kaygısı ve işyeri yalnızlığı betimsel istatistikleri

\begin{tabular}{lcccccc}
\hline & \multicolumn{2}{c}{$\begin{array}{c}\text { Kadın } \\
(\mathbf{n = 6 5})\end{array}$} & \multicolumn{2}{c}{$\begin{array}{c}\text { Erkek } \\
(\mathbf{n = 1 2 7})\end{array}$} & \multicolumn{2}{c}{$\begin{array}{c}\text { Tüm Katılımcılar } \\
(\mathbf{n = 1 9 2})\end{array}$} \\
\cline { 2 - 7 } Değişkenler & Ort & SS & Ort & SS & Ort & $S \boldsymbol{S}$ \\
\hline Duygusal yoksunluk & 2.04 & 0.76 & 2.15 & 0.77 & 2.11 & 0.76 \\
Sosyal arkadaş̧1k & 2.11 & 0.78 & 2.05 & 0.79 & 2.07 & 0.79 \\
Sosyal görünüş kaygısı & 1.65 & 0.61 & 1.72 & 0.66 & 1.69 & 0.64 \\
\hline
\end{tabular}

Sosyal görünüş kaygısı, İşyerinde Yalnızlık Ölçeği’ nin duygusal yoksunluk ve sosyal arkadaşlık alt boyutları ile yaş, eğitim ve çalışma süresi arasındaki ilişkileri belirlemek amacıyla Pearson Momentler Çarpımı Korelasyon Analizi yapılmıştır. Korelasyon analizi sonuçları Tablo 3'de sunulmuştur.

Tablo 3. Korelasyon Analizi Sonuçları

\begin{tabular}{lcccc}
\hline Değişkenler & SA & SGK & Yaş & Çalışma Süresi \\
\hline Duygusal Yoksunluk (DY) & $0.69^{* *}$ & $0.51^{* *}$ & 0.11 & 0.13 \\
Sosyal Arkadaşlık (SA) & & $0.37^{* *}$ & 0.01 & 0.04 \\
Sosyal Görünüş Kaygı1s1 (SGK) & & & 0.07 & $0.18^{*}$ \\
**p<0.01, *p<0.05 & & &
\end{tabular}

Sosyal görünüş kaygısı duygusal yoksunluk $(r=0.51, \mathrm{p}<.01)$ ve sosyal arkadaşlık $(\mathrm{r}=0.37$, $\mathrm{p}<.01$ ) alt boyutları birbiriyle pozitif yönde ilişkili bulunmuştur. Buna ek olarak sosyal görünüş kaygısı ayrıca çalışma süresi $(r=0.18, \mathrm{p}<.05)$ ile pozitif ilişkili bulunmuştur. 
Sosyal görünüş kaygısının iş yeri yalnızlığının duygusal yoksunluk ve sosyal arkadaşlık alt boyutlarını yordama düzeyinin belirlenmesi amacıyla basit regresyon analizi yapılmıştır. Analiz sonuçları Tablo 4 ve Tablo 5' de sunulmuştur.

Tablo 4. Katılımcıların sosyal görünüş kaygısının duygusal yoksunluğu ne derece yordadığına ilişkin basit regresyon analizi bulguları

\begin{tabular}{lcccll}
\hline Duygusal yoksunluk & B & SH & $\boldsymbol{\beta}$ & $\mathbf{t}$ & $\mathbf{p}$ \\
\hline Sabit & 1.00 & .14 & & 7.28 & $>0.001$ \\
Sosyal Görünüş Kaygısı & .63 & .07 & .51 & 8.24 & $>0.001$ \\
$\mathrm{n}=192, \mathrm{R}=.51, \mathrm{R}^{2}=.26 \mathrm{~F}=67.83, \mathrm{p}<.001$ & & & \\
\hline
\end{tabular}

Tablo 4'teki basit regresyon analizi sonuçlarına bakıldığında, sosyal görünüş kaygısının duygusal yoksunluğu anlamlı düzeyde açıkladığı görülmektedir $\left[\mathrm{R}=.51, \mathrm{R}^{2}=.26, \mathrm{~F}=67.83\right.$, $\mathrm{p}<.001]$. Regresyon katsayısının anlamlılığına ilişkin t-testi sonuçları incelendiğinde ise sosyal görünüş kaygısı ( $\beta$ : .51) duygusal yoksunluk arasında pozitif yönde anlamlı ilişki olduğu ve sosyal görünüş kaygısı düzeyinin katılımcıların duygusal yoksunluğunun \%26'sını yordadığ1 görülmektedir.

Tablo 5. Katılımcıların sosyal görünüş kaygısının sosyal arkadaşlığı ne derece yordadığına ilişkin basit regresyon analizi bulguları

\begin{tabular}{lccccc}
\hline Sosyal arkadaşlık & B & SH & B & t & p \\
\hline Sabit & 1.38 & .15 & & 9.45 & $>0.001$ \\
Sosyal Görünüş Kaygısı & .43 & .08 & .36 & 5.40 & $>0.001$ \\
$\mathrm{n}=192, \mathrm{R}=.37, \mathrm{R}^{2}=.13 \mathrm{~F}=29.14, \mathrm{p}<.001$ & & & \\
\hline
\end{tabular}

Tablo 5'deki basit regresyon analizi sonuçlarına bakıldığında, sosyal görünüş kaygısının sosyal arkadaşlık alt ölçeğini anlamlı düzeyde açıkladığı görülmektedir $\left[\mathrm{R}=.37, \mathrm{R}^{2}=.13\right.$, $\mathrm{F}=29.14, \mathrm{p}<.001]$. Regresyon katsayısının anlamlılığına ilişkin t-testi sonuçları incelendiğinde ise sosyal görünüş kaygısı ( $\beta$ : .36) ile sosyal arkadaşlık arasında pozitif yönde anlamlı ilişki olduğu ve sosyal görünüş kaygısı düzeyinin katılımcıların sosyal arkadaşlık alt ölçeğini \%13'ünü yordadığı görülmektedir.

\section{Tartışma ve Sonuç}

$\mathrm{Bu}$ çalışmanın amacı, Konya Gençlik ve Spor İl Müdürlüğü’nde çalışan personelin sosyal görünüş kaygıları ile iş yaşamında yalnızlık durumları arasındaki ilişkiyi incelemek ve katılımcıların yaş ve çalışma süresi gibi özellikleri ile araştırmada ele alınan kavramlar arasında herhangi bir ilişki olup olmadığı araştırmaktır. 
İncelenen literatür taramasında sosyal görünüş kaygısı ile iş yaşamında yalnızlık arasındaki ilişkiyi birlikte değerlendiren başka bir çalışma bulgusuna rastlanmamıştır. Yalnızlık kavramı alanyazında, araştırmamızda ele alınan sosyal görünüş kaygısına yakın olan, sosyalleşme, umutsuzluk, kaygı, depresyon ve yaşam kalitesi gibi konular ile ilişkileri ele alınmıştır (Korkmaz ve Uslu, 2020; Cindiloğlu, Polatcı, Özçalık ve Gültekin, 2017; Yılmaz, 2019).

Araştırmadan elde edilen bulgulara göre gençlik ve spor çalışanlarında sosyal görünüş kaygısı arttıkça İşyerinde Yalnızlık Ölçeği’nin duygusal yoksunluk ve sosyal arkadaşlık alt boyutlarında da artış görülmüştür. Yalnızlık konusunda ilk görüşleri ortaya koyan hümanist ve varoluşçu teorisyenler yalnızlığı, kendini reddetmeye yol açan bir kayg1 biçimi olarak tanımlamışlardır (Moustakas, 1961). Bu tür teorisyenler yalnızlığı paradoksal olarak, hem başkalarının içsel benliği anlamayacağına ve kabul etmeyeceğine inanmanın patolojik bir yansıması (Rogers, 1970) hem de öz-farkındalığı derinleştiren normal bir deneyim (Mijuskovic, 1979) olarak ele aldılar. Duygusal yalnızlığın teorik dayanakları göz önüne alındığında, sosyal yalnızlığın daha fazla depresyon ve kaygı ile ilişkili olduğu bulunmuştur. Moore ve Schultz (1983) yalnızlık ile sosyal kaygı arasında bir ilişki olduğunu belirtmiştir. Kaygı ile yalnızlık arasındaki bu pozitif ilişki araştırmamızdaki sosyal görünüş kaygısı ile yalnızlığın alt boyutları arasındaki ilişkiyi destekler niteliktedir. Amil ve Bozgeyikli (2015) üniversite öğrencileri ile yaptıkları çalışmada, öğrencilerin sosyal görünüş kaygıları ile yalnızlık düzeyleri arasında pozitif yönde anlamlı bir ilişki bulmuşlar; artan sosyal görünüş kaygısının yalnızlık düzeyinin artmasıyla sonuçlandığını belirtmişlerdir. Eren Gümüş (2000) üniversiteliler ile yaptığı çalışmada sosyal kaygının bir çeşidi olan beden imaj doyumu ile yalnızlık arasında pozitif yönde anlamlı bir ilişki olduğunu ortaya koymuştur. Kılıç (2015) yaptığı çalışmada üniversite öğrencilerinin yalnızlıkları arttıkça sosyal görünüş kaygılarının da arttığını bulunmuştur. Çalışanların kendi fiziksel görünümleri ile ilişkili olumsuz değerlendirildiklerine ilişkin algıları iş yerinde sosyal ilişkilerinin duygusal niteliği ve nicelik olarak arkadaşa sahip olma durumlarını olumsuz etkilediği görülmüştür. Bu durum katılımcıların fiziksel görünümleriyle ilgili olumsuz değerlendirmelerinin bir yansıması olabilir.

Konya Gençlik ve Spor İl Müdürlüğü çalışanlarının İşyerinde Yalnızlık Ölçeği'nin duygusal yoksunluk ve sosyal arkadaşlık alt ölçekleri ile katılımcıların yaşları ve çalışma süreleri arasında anlamlı bir ilişki bulunmamıştır. Yalnızlık ve çalışma süresi konusunda literatürde herhangi bir çalışmaya rastlanmamış olup, işyerinde, farklı iş özelliklerinin yalnızlık üzerinde belirli bir etkisi olduğu belirtilmiştir. Bell ve ark. (1991) çalışma saatlerinin üyelerin yalnızlığını etkili bir şekilde tahmin edebileceğini bulmuştur. Çalışma saatleri ne kadar uzun olursa, çalışanların kişilerarası ilişkileri görmezden gelmesinin o kadar kolay olduğu ve 
yalnızlığı deneyimleme olasılıklarının arttığı belirtilmiştir. Çalışma saatlerindeki artış ile yalnızlık arasındaki ilişkiyi olumlu yöne çeviren kavram ise takım uyumu ve ekibin bağlılığı olduğu araştırmalarda söylenmektedir. Ayrıca çok fazla iş yükü olan kurumlarda işyeri yalnızlığı ile yorgunluk, tükenmişlik, kişilerarası ilişkilerde sorunlarla başa çıkmak için zaman ve enerji eksikliği arasında pozitif yönde anlamlı bir ilişki bulunmuştur (Wright, 2005).

Katılımcılarının çalışma süreleri arttıkça sosyal görünüş kaygılarının da arttığı araştırmadan elde edilen bir diğer bulgudur. Bu bulgu katılımcıların uzun yıllar aynı yerde çalışmanın kendi fiziksel görünümleriyle ilişkili algılarını olumsuz yönde etkilediğini belirtmektedir. Literatürde sosyal görünüş kaygısı iş yerlerinde ele alınmamış, genellikle farklı ortamlarda (lise ve üniversite öğrencileri, sporcular, kadınlar...vb.) araştırmaya konu olmuştur. Dolayısı ile çalışma süresi ve sosyal görünüş kaygısına yönelik bulgulara alanyazında rastlanmamıştır.

Sonuç olarak, Konya ilinde gençlik ve spor çalışanlarından fiziksel görünümlerinin başkaları tarafından olumsuz değerlendirildiğine yönelik algıya sahip olanların işyerinde arkadaş ilişkilerinin özelliklerini ve arkadaş edinme sayısını olumsuz etkilediği bu çalışmada ile elde edilen bulgudur. Çalışmamızın önemli bulguları yanında, sınırlılıklarını da bulunmaktadır. Bu araştırma sadece ülkemizde sporun yönetilmesinden sorumlu olan Gençlik ve Spor Genel Müdürlügü’ nün taşra teşkilatı olan Konya Gençlik ve Spor İl Müdürlügü’ nde çalışan bireyler ile sınırlı olup, gelecekteki araştırmalar farklı meslek grupları üzerinde araştırmalar yaparak söz konusu psikolojik kavramlara ilişkin bulguları genişletebilir. Özel sektör ve yaşanılan bölge örneğin daha kırsal kesimlerde yalnızlık ve sosyal görünüş kaygısına yönelik bulgular farklılaşabilir. Dolayısıyla farklı yaş gruplarından, farklı bölgeler ve çalışma şartlarındaki bireylerin dahil olduğu araştırmalar yapılmalıdır. Nitel araştırma yöntemleri kullanılarak araştırmaya konu olan kavramlar daha derinlemesine ortaya konulabilir. Yalnızlık, kaygı, zayıf beden imgesi, kişilerarası ilişkilerin kötü olması ve düşük benlik saygısından ile ilişkili ise, o zaman neden organizasyonlarda üst düzey pozisyonlarda bulunan başarılı bireylerin genellikle yalnızlık duygusunu hissettiklerini bildirmeleri ilginçtir. Gelecekte yapılacak çalışmalar nitel araştırma yöntemleriyle üst pozisyonda çalışan bireylerin yalnızlık nedenlerine odaklanırsa bu konuda yapılan çalışmalara ilişkin bulgular genişletilebilir. 


\section{KAYNAKLAR}

Akbaba M. (2020). İnsan kaynakları yönetimi uygulamaları ile iş yaşamında yalnızlık arasındaki ilişki: otel işletmeleri üzerine bir araştırma. Turkish Studies-Social, 15(4), 1701-1716.

Amil O., Bozgeyikli H. (2015). Investigating the relationship between social appearance anxiety and loneliness of turkish university youth. Journal of Studies in Social Science. 11(1), 68-96.

Aykan E., Karakuş G., Karakoç H. (2019). İş yaşamında yalnızlık algısı ve iş stresinin örgütsel bağlılık üzerindeki etkisi: Erciyes Üniversitesi idari personeli örneği, Ekonomi ve Yönetim Araştırmaları Dergisi, 8 (1), 4161.

Bilgener E., Çankaya M. (2019). İş yaşamı yalnızlığının çalışma ortamını değerlendirme üzerindeki etkileri: hemşire meslek grupları üzerinde bir araştırma. Insan ve Toplum Bilimleri Araştırmaları Dergisi, 8 (4), 2485-2500.

Cacioppo, J. T., Hawkley, L. C., \& Thisted, R. A. (2010). Perceived Social Isolation Makes Me Sad: 5-Year CrossLagged Analyses of Loneliness and Depressive Symptomatology in the Chicago Health, Aging, and Social Relations Study. Psychology and Aging, 25, 453-463. https://doi.org/10.1037/a0017216

Çakmak A., Sakarya S. (2020). Farklı türde liselere devam eden öğrencilerin sosyal görünüş kaygıları ile sosyal karşılaştırma düzeyleri arasındaki ilişkinin incelenmesi. Elektronik Sosyal Bilimler Dergisi, 19(74), 680691.

Cindiloğlu Demirer M., Polatcı S., Özçalık F., Gültekin Z. (2017). İşyeri yalnızlığının iş ve yaşam tatminine etkisi: lider-üye etkileşiminin aracılık rolü. Ege Akademik Bakış, (17 (2), 191-200.

Çetin A., Alacalar A. (2016). İş yaşamında yalnızlığı yordamada kişilik özellikleri ile algılanan sosyal ve örgütsel desteğin rolü. Uluslararası Yönetim İktisat ve İşletme Dergisi. 12(27), 193-216.

Cindiloğlu, M., Polatcı, S., Özçalık, F., \& Gültekin, Z. (2017). İşyeri Yalnızlığının İş ve Yaşam Tatminine Etkisi: Lider-Üye Etkileşiminin Aracılık Rolü. Ege Academic Review, 17(2).

Doğan T., Çetin B., Sungur MZ. (2009). İş yaşamında yalnızlık ölçeği Türkçe formunun geçerlilik ve güvenilirlik çalışması. Anadolu Psikiyatri Dergisi, 10, 271-277.

Doğan T. (2010). Sosyal görünüş kaygısı ölçeğinin (SGKÖ) Türkçe uyarlanması: geçerlik güvenirlik çalışması. Hacettepe Üniversitesi Ĕ̈itim Fakültesi Dergisi, 39, 151-159.

Eren Gümüş A. (2000). Üniversite öğrencilerinin yalnızlık ve beden imgelerinden doyum düzeylerinin sosyal kaygı düzeyleri ile ilişkisinin incelenmesi. Ankara Üniversitesi Eğitim Bilimleri Fakültesi Dergisi. 33(1), 99-108.

Gafa İ., Dikmenli Y. (2019). Sınıf öğretmenlerinin iş doyumu ve iş yaşamındaki yalnızlık düzeylerinin incelenmesi. Ahi Evran Üniversitesi Sosyal Bilimler Enstitüsü Dergisi, 5 (1), 131-150.

Göksel AG., Caz Ç., Yazıcı ÖF., Zorba E. (2018) Spor hizmeti alan bireylerin sosyal görünüş kaygısı ve öznel mutluluklarının incelenmesi. Gaziantep Üniversitesi Spor Bilimleri Dergisi, 3 (3), 88-101.

Hart TA., Flora DB., Palyo SA., Fresco DM., Holle C., Heimberg RC. (2008). Development and examination of the social appearance anxiety scale. Assessment. 15(1), 48-59.

Kara A. (2016). Sosyal görünüş kaygısı ile utangaçlık arasındaki ilişkilerin incelenmesi. Birey ve Toplum. 6(11), 95-106.

Karasar N. (2020). Bilimsel araştırma yöntemi: kavramlar, ilkeler, teknikler. Ankara: Nobel Yayıncılık 36. Basım.

Kılıç M. (2015). Üniversite öğrencilerinin sosyal görünüş kaygıları ile benlik saygıları ve yalnızlık düzeyleri arasındaki ilişkinin incelenmesi. Selçuk Üniversitesi Sağlık Bilimleri Enstitüsü Yüksek Lisans Tezi.

Kılıç M., Karakuş Ö. (2016). Üniversite öğrencilerinin sosyal görünüş kaygıları ile benlik saygıları ve yalnızlık düzeyleri arasındaki ilişkinin incelenmesi. Journal of Human Sciences, 13(3), 3837-3852.

Koçak O., Şimşek MO. (2018). Türk ve yabancı öğrencilerin karşılaştırmalı olarak sosyal görünüş kayg1 düzeylerinin değerlendirilmesi. Middle East Journal of Refugee Studies, 4 (1), 23-37.

Koçak E., Tunç B. (2020). İş doyumu ve çalışma yaşamında yalnızlık: Mersin Üniversitesi idari çalışanlarına ilişkin bir araştırma. Manas Sosyal Araştırmalar Dergisi, 9 (4), 2092-2112.

Koçer C., Yeşil E., Yürüyen H. (2018). Sanallık algısının, işyeri yalnızlığı ve örgütsel iletişim üzerindeki etkisi. Uluslararası Turizm, İşletme, Ekonomi Dergisi, 2 (2), 561-577.

Korkmaz M., Uslu T. (2020). Fitness yapan bireylerin benlik saygısı, sosyal görünüş kaygısı ve sosyalleşme düzeyleri arasındaki ilişkilerin incelenmesi. Spor Ĕ̌itim Dergisi, 4 (3), 1-18.

Lam, L. W., \& Lau, D. C. (2012). Feeling Lonely at Work: Investigating the Consequences of Unsatisfactory Workplace Relationships. International Journal of Human Resource Management, 23, 4265-4282. https://doi.org/10.1080/09585192.2012.665070

Mijuskovic, B. (1979). Loneliness in philosophy, psychology, and literature. Assen: Van Gorcum.

Moore, D., Schultz, N. (1983). Loneliness at adolescence: Correlates, attributions, and coping. Journal of Youth \& Adolescence, 12 (2), 95-100.

Moustakas, C. (1961). Loneliness. Englewood Cliffs, NJ: Prentice-Hall.

Özmen M. (2019). İşyerinde yalnızlığı etkileyen örgütsel güven unsurlarının cinsiyeti göre değişimi: havalimanı çalışanları üzerine bir araştırma. İş ve Insan Dergisi, 7 (1), 77-88. 
Parlak Ö., Koçoğlu Sazkaya M. (2018). Beş faktör kişilik özelliklerinin iş yaşamında yalnızlık üzerine etkisinin incelenmesi. Ordu Üniversitesi Sosyal Bilimler Araştırmaları Dergisi, 8 (1), 149-165.

Rogers, C. (1970) On Encounter Groups. New York: Harper and Row.

Sever E., Paksoy M. (2019). Personel güçlendirmenin iş yaşamında yalnızlık üzerindeki etkisinde kişilik özelliklerinin aracılık rolü. Opus Uluslararası Toplum Araştırmaları Dergisi, 9 (12), 373-409.

Şimşir Z., Dilmaç B. (2019). Sosyal görünüş kaygısında cinsiyet farklılıkları: bir meta analiz çalışması. Opus Uluslararası Toplum Araştırmaları Dergisi, 10 (17), 615-637.

Tabachnick BG., Fidell LS. (2001). Using multivariate statistics. Boston: Ally\&Bacon.

Wright SL. (2005). Loneliness in the Workplace. Unpublished Doctoral Dissertation, Christchurch (New Zealand), University of Canterbury.

Wright SL., Burt CDB., Strongman KT. (2006). Lonelines in the workplace: construct definition and scale development. New Zealand Journal of Psychology. 35(2), 59-68.

Yılmaz, Y. E. (2019). Üniversite ögrencilerinin duygusal zekaları, sosyal görünüş kaygıları ve umutsuzluk düzeyleri arasındaki ilişkinin incelenmesi (Master's thesis, Hasan Kalyoncu Üniversitesi).

Zhou, X. (2018). A review of researches workplace loneliness. Psychology, 9(5), 1005-1022. 